\title{
Modelling impacts of spatially variable erosion drivers on suspended sediment dynamics
}

\author{
Giulia Battista, Peter Molnar, and Paolo Burlando \\ Institute of Environmental Engineering, ETH Zurich, 8093 Zurich, Switzerland \\ Correspondence: Giulia Battista (battista@ifu.baug.ethz.ch)
}

Received: 18 October 2019 - Discussion started: 6 November 2019

Revised: 2 June 2020 - Accepted: 8 June 2020 - Published: 16 July 2020

\begin{abstract}
Suspended sediment load in rivers is highly uncertain because sediment production and transport at catchment scale are strongly variable in space and time, and they are affected by catchment hydrology, topography, and land cover. Among the main sources of this variability are the spatially distributed nature of overland flow as an erosion driver and of surface erodibility given by soil type and vegetation cover distribution. Temporal variability mainly results from the time sequence of rainfall intensity during storms and snowmelt leading to soil saturation and overland flow.

We present a new spatially distributed soil erosion and suspended sediment transport module integrated into the computationally efficient physically based hydrological model TOPKAPI-ETH, with which we investigate the effects of the two erosion drivers - precipitation and surface erodibility - on catchment sediment fluxes in a typical pre-Alpine mesoscale catchment. By conducting a series of numerical experiments, we quantify the impact of spatial variability in the two key erosion drivers on erosion-deposition patterns, sediment delivery ratio, and catchment sediment yields.

Main findings are that the spatial variability in erosion drivers affects sediment yield by (i) increasing sediment production due to a spatially variable precipitation, while decreasing it due to a spatially variable surface erodibility, (ii) favouring the clustering of sediment source areas in space by surface runoff generation, and (iii) decreasing their connectivity to the river network by magnifying sediment buffers. The results highlight the importance of resolving spatial gradients controlling hydrology and sediment processes when modelling sediment dynamics at the mesoscale, in order to capture the key effects of sediment sources, buffers, and hillslope hydrological pathways in determining the sediment signal.
\end{abstract}

\section{Introduction}

Fine sediment produced in catchments by upland erosion and transported by rivers as suspended load is an important part of the global sediment budget (e.g. Peucker-Ehrenbrink, 2009) and an important driver of water quality and aquatic biota in rivers (e.g. Bilotta and Brazier, 2008). Human activity strongly interacts with the natural processes of suspended sediment production and transport, on the one hand by practices that enhance soil erosion, like agriculture, mining, and deforestation, and on the other hand with the construction of sediment retention structures such as dams (e.g. Syvitski et al., 2005; Montgomery, 2007; Syvitski and Kettner, 2011; Borrelli et al., 2017). In the context of enhanced soil ero- sion, phenomena like the loss of soil productivity, the reduction of water quality due to higher turbidity and concentration of pollutants, and accelerated reservoir siltation are expected (e.g. Pimentel et al., 1987; Davies-Colley and Smith, 2001). The combined effect of enhanced soil erosion and sediment retention by dams modifies the river sediment equilibrium and can result in river incision in the case of sediment starvation, contributing to the undermining of the stability of bridges and other infrastructures and leading to coastal erosion (Kondolf, 1997; Chen and Zong, 1998; Schmidt and Wilcock, 2008). The opposite case of excessive sediment load in rivers may lead to an increase in flood risk in alluvial floodplains due to sediment deposition (Yu, 2002; Walling, 
2006; Rickenmann et al., 2016). The intensity of these effects is expected to grow in the future, as the magnitude and number of highly erosive extreme precipitation events are foreseen to increase in some parts of the world due to climate change and/or anthropic influence on land cover (e.g. Yang et al., 2003; Nearing et al., 2004; Peleg et al., 2020). Therefore, the monitoring and understanding of suspended sediment dynamics is essential to explain how disturbances produced by such human interventions may affect the sediment balance.

Fine sediment yield in rivers is usually estimated from intermittent measurements of sediment concentration by means of sediment-discharge rating curves (see Gao, 2008, for a review). However, the development and use of these curves is often highly problematic because of the strong nonuniqueness of suspended sediment concentrations (SSCs), especially in small to medium sized catchments (up to $\left.1000 \mathrm{~km}^{2}\right)$. Here, the same value of discharge $(Q)$ often leads to a wide range of SSCs, producing highly scattered SSC$Q$ rating curves (e.g. Walling, 1977; Walling and Webb, 1982; Ferguson, 1986; Asselman, 2000; Horowitz, 2003). The strong variability in SSC is attributed to the high nonlinearity of the sediment production and transport processes in time and space and the presence of threshold and feedback mechanisms in sediment mobilization and transfer (e.g. Asselman, 1999; Collins and Walling, 2004; Seeger et al., 2004; Fryirs et al., 2007; Bracken et al., 2015).

Temporal and spatial variability in suspended sediment transport can originate from several sources (see Vercruysse et al., 2017, for a review). Among the sources of temporal variability, the role of hydrometeorological conditions (e.g. rainfall, antecedent wetness conditions, runoff) has been widely investigated, with a particular focus on the shape and direction of the hysteresis loops of the SSC $-Q$ relation (Smith et al., 2003; Seeger et al., 2004; Zabaleta et al., 2007; Duvert et al., 2010; Dominic et al., 2015; Misset et al., 2019). Other sources of variability are the exhaustion of preferential sediment sources, the activation of new ones, and changes in the connectivity of such sources to the river network. These aspects have been studied for example as consequences of land use change and flow regulation (Olarieta et al., 1999; Siakeu et al., 2004; Costa et al., 2018). Variability in sediment transport in space depends on the distribution of sediment sources within the catchment, the catchment sediment connectivity, and the efficiency of sediment transport within the stream network. Wass and Leeks (1999) related differences in sediment loads across the basin to geomorphic and climatic gradients, while Fryirs and Brierley (1999) and Lang et al. (2003) reconstructed the change of sediment sources in time and their coupling with the channels. The problem of catchment sediment connectivity has been addressed from a conceptual point of view, by introducing the ideas of structural and functional connectivity, to distinguish between the physical connection among landscape units and the connectivity generated by the system process interactions (Wain- wright et al., 2011; Fryirs, 2013; Bracken et al., 2015). Based on these concepts, several indices have been introduced to assess sediment connectivity in a river basin (see Heckmann et al., 2018, for a review).

The above studies highlight the need to account for both types of variability (temporal and spatial) in order to investigate basin sediment dynamics. Including this variability is especially important at the medium and large catchment scale and in mountainous environments, where the gradients of climatic and physiographic variables are most relevant. Few studies have focused specifically on the impacts of spatially variable erosion drivers on suspended sediment dynamics in such environments. A systematic investigation of this research gap can be performed by means of numerical models that include the main hydrological processes, their temporal dynamics and distribution in space, and their interaction with the topography and morphology of the basin. Several existing models are partially suitable for this task. The main limitations are that many are only suitable for event applications (Answers, Beasley et al., 1980; KINEROS, Woolhiser et al., 1990; WEPP, Nearing et al., 1989) or present simplified hillslope hydrology and runoff formation solutions, as in the case of WATEM/SEDEM (Van Rompaey et al., 2001), landscape evolution models, e.g. CAESAR-Lisflood (Coulthard et al., 2013), and SIBERIA (Hancock et al., 2000), or some largescale sediment flux models, e.g. WBMsed (Cohen et al., 2013) and Pelletier (2012). More suitable approaches are tRIBS (Francipane et al., 2012), which includes a physically based hydrological component suitable for long-term process simulations, and DSHVM (Doten et al., 2006), which features a detailed hydrology-vegetation component and sediment module. However, the number of processes represented in these two models requires high computational power, and their applications have so far been limited to small basins and/or short timescales. Finally, Tsuruta et al. (2018) present a spatially distributed model especially for large basins, which, being based on a land-surface model, features an approximated coarse-scale representation of hydrological and sediment connectivity on the hillslopes.

In this work we present a modelling approach especially suitable for Alpine catchments with highly variable climate and complex topography. The approach integrates a new spatially distributed soil erosion and suspended sediment transport module within the computationally efficient, physically based hydrological model TOPKAPI-ETH (Fatichi et al., 2015). The model combines unsteady simulation of surface and subsurface water fluxes with a simple hillslope erosion and sediment transport component. The sediment component is simple by design, to avoid over-parameterization and to maintain computational efficiency enabling applications to large catchments. The model allows continuous high spatial resolution $(\Delta x=100 \mathrm{~m})$ simulations to track overland flow and hillslope sediment transport by local changes in soil moisture produced by rainfall, snowmelt, and lateral drainage over long periods of time. The model also allows high tem- 
poral resolution $(\Delta t=1 \mathrm{~h}$ ) simulations to capture fast runoff response to the hydrological drivers, which, together with the topographically driven flow routing, reproduces the connectivity of water and sediment pathways in the catchment over time. The combined hydrology-sediment model is unique in its process completeness and applicability to mesoscale catchment simulation at high resolutions, compared to most other approaches.

The overall aim of this research is to provide a state-ofthe-art catchment hydrology-sediment modelling framework to better understand the sources of variability in suspended sediment concentrations and their effects on predictions of sediment yield. Accordingly, we conducted numerical experiments on a mesoscale pre-Alpine river basin, where we turned on and off the spatial variability in two key erosion drivers - rainfall and surface erodibility - to quantify their individual and combined effect on suspended sediment mobilization and transfer. We address the following specific research questions. (RQ1) Does fully distributed physically based hydrology-sediment modelling predict variability in SSC $-Q$ relations that is in agreement with observations? We argue which key hydrological processes are needed in such a model and why. (RQ2) Can we identify the location of sediment sources and quantify their productivity and connectivity with such a modelling approach? We assess the effect of the spatial distribution of rainfall and surface erodibility on hillslope erosion-deposition patterns and sediment mobilization, and we quantify the sediment source connectivity to the river network by analysing the sediment delivery ratio along the main stream and in tributary basins. (RQ3) Is the effect of spatially distributed erosion drivers visible in sediment yield at the catchment outlet? We show how integration of the spatially variable inputs in space impacts sediment yield under different scenarios.

\section{Methods}

\subsection{Hydrology-sediment model description}

The model we present in this work is an extension of the hydrological model TOPKAPI-ETH (Fatichi et al., 2015), which we integrated with a new hillslope erosion and channel suspended sediment flow module. The TOPKAPI-ETH hydrological model was chosen because of its spatially distributed nature and physically based representation of the major hydrological processes, combined with a reasonable computational demand. The model is based on a regular square grid discretization in space and a three-layer vertical discretization of the subsurface. The river network is identified in the domain by means of a flow accumulation algorithm based on the topography. The transition between hillslope and channel process description, i.e. the beginning of the model river network, is set by a user-defined critical upstream area, or river initiation threshold RT, above which water flow is modelled as channel flow. Each river network cell can be fully or partially covered by the stream, depending on the actual stream width and grid cell resolution.

In TOPKAPI-ETH surface and subsurface flow is simulated by the kinematic wave approximation, with resistance to flow given by surface roughness and soil transmissivity as a function of soil properties. Water may saturate the soil locally and lead to overland flow generation by saturation excess or by infiltration excess in case of high rainfall intensities. Soil moisture is depleted by evapotranspiration, lateral drainage and percolation to groundwater storage. The model includes snow cover accumulation and melt, which are important in the water balance of Alpine basins. For further details about the model see Fatichi et al. (2015). TOPKAPI-ETH allows long-term, high-resolution simulations (time step $\Delta t=1 \mathrm{~h}$; grid size $\Delta x=100 \mathrm{~m}$ ) in medium and large catchments $\left(>1000 \mathrm{~km}^{2}\right)$, even when integrated with a sediment mobilization and transfer component, since the kinematic wave approximation of the surface and subsurface flow routing is solved analytically (Liu and Todini, 2002).

In the new sediment module of TOPKAPI-ETH, the mobilization and routing of fine sediment on the hillslopes takes place by action of overland flow, which is assumed to transport sediment at its maximum capacity. As a consequence, deposition and erosion can occur on the hillslopes at a rate $D\left(\mathrm{~kg} \mathrm{~m}^{-3} \mathrm{~s}^{-1}\right)$ depending on the hydraulic and topographic properties of the cells along the flow path:

$D=\nabla \cdot q_{\mathrm{s}}$,

where $q_{\mathrm{s}}\left(\mathrm{kg} \mathrm{m}^{-2} \mathrm{~s}^{-1}\right)$ is the overland flow sediment transport capacity, modelled following Prosser and Rustomji (2000) as a function of the specific overland flow discharge $q\left(\mathrm{~m}^{2} \mathrm{~s}^{-1}\right)$ and the surface slope $S\left(\mathrm{~m} \mathrm{~m}^{-1}\right)$ :

$q_{\mathrm{s}}=\alpha q^{\beta} S^{\gamma}$,

where $\beta$ and $\gamma$ are transport exponents, and $\alpha$ is a calibration parameter that captures the effect of land surface and soil properties on erosion and sediment transport. The sediment flux $q_{\mathrm{s}}$ is directed to the downstream cell with the steepest gradient. Sediment inflow into a cell can be from one or more upstream cells. Once the sediment mobilized and routed on the hillslopes reaches the channel, it is assumed to move as suspended sediment load.

The suspended sediment flux in the river network is treated as an advection process and solved with the same numerical methods used for water flow. The 1D equation of suspended sediment flux in the channel, integrated over the river cross section, is

$\frac{\partial A C}{\partial t}=E-\frac{\partial Q C}{\partial x}$,

where $Q\left(\mathrm{~m}^{3} \mathrm{~s}^{-1}\right)$ is the river discharge, $C\left(\mathrm{~g} \mathrm{~m}^{-3}\right)$ is the SSC, $A\left(\mathrm{~m}^{2}\right)$ is the cross section area of flow, and $E$ 
$\left(\mathrm{g} \mathrm{m}^{-1} \mathrm{~s}^{-1}\right)$ represents the exchange of sediment with the bed and local sediment sources. By following the reasoning of Liu and Todini (2002), Eq. (3) can be integrated along the length of the grid cell (i.e. in the flow direction), within which the values of the variables are assumed to be constant, and then solved analytically as a first-order ordinary differential equation:

$$
\frac{\partial V_{i} C_{i}}{\partial t}=E_{i} X+Q_{\text {in }} C_{\text {in }}-\frac{U_{i}}{X} C_{i} V_{i},
$$

where $X(\mathrm{~m})$ is the length of the grid cell, $V_{i}\left(\mathrm{~m}^{3}\right)$ the volume of water inside a cell $\left(V_{i}=A_{i} X_{i}\right), U_{i}\left(\mathrm{~m} \mathrm{~s}^{-1}\right)$ is the mean flow velocity, and $C_{i}$ and $E_{i}$ are the mean values of $C$ and $E$ inside the grid cell. $Q_{\text {in }}$ and $C_{\text {in }}$ are the discharge and sediment concentration entering the cell $i$ from the upstream grid cells.

\subsection{Study site}

We chose to investigate the research questions outlined above on the Kleine Emme river basin, a pre-Alpine catchment located in central Switzerland. Here the natural regime of water and sediment flow is almost unaltered, and the basin is sufficiently large for spatial variability in erosion drivers to have an impact. The basin has an area of $477 \mathrm{~km}^{2}$, an elevation range of 430-2300 $\mathrm{m}$ a.s.1., and a mean annual precipitation of $1650 \mathrm{~mm}$ (Fig. 1a). The mean annual discharge at the outlet is $12.6 \mathrm{~m}^{3} \mathrm{~s}^{-1}$. The catchment is mostly natural, with more than $50 \%$ of the surface covered by forest and grassland (Fig. 1c). No use of water for irrigation or hydropower is known, and significant sediment-retaining infrastructures are absent. Moreover, the absence of glaciers means that fine sediment production in the basin is mostly driven by overland flow and rainfall processes. Finally, the diverse geomorphology of the basin has been the subject of several studies, and long-term estimates of denudation rates are available (e.g. Schlunegger and Schneider, 2005; Schwab et al., 2008; Dürst Stucki et al., 2012; Van Den Berg et al., 2012; Clapuyt et al., 2019).

Measurements of precipitation, air temperature and sunshine duration are available from automatic weather stations located inside or in the vicinity of the basin operated by MeteoSwiss. The information about the spatial distribution of precipitation inside the basin is available from the $1 \mathrm{~km} \times 1 \mathrm{~km}$ daily gridded product of MeteoSwiss RhiresD (Frei and Schär, 1998; Schwarb, 2000). Streamflow is monitored at Werthenstein and at the basin outlet by the Federal Office of the Environment (FOEN) and at Sörenberg by the canton of Lucerne (Fig. 1a). FOEN also provided the cross section measurements for the main channel of the river and measurements of suspended sediment concentration. SSCs have been manually sampled at the outlet since 1974 but with a regular frequency of two samples a week only since 2004. Because of the low temporal resolution of these measurements, which is typical of many river sediment monitoring networks, we expect this dataset to miss extreme SSCs generated by flood events or very localized sediment sources. Finally, the information about soil type and depth for the basin is available from the soil map of Switzerland (Bodeneignungskarte, 2012) (Fig. 1b), and land cover is provided by the Corine Land Cover dataset (Fig. 1c).

\subsection{Model setup and calibration}

\subsubsection{Hydrology}

Given the period of availability of suspended sediment measurements in the Kleine Emme, the simulation was set up for the years 2003 to 2016, where the first year is considered a warm-up period. The meteorological input data required by the hydrological component of TOPKAPI-ETH are hourly precipitation, air temperature, and cloud cover. The precipitation input file was created by combining station and gridded precipitation datasets following the approach of Paschalis et al. (2014). In this approach hourly precipitation measured at the rain gauges was spatially interpolated to match the spatial distribution of the daily precipitation in the gridded RhiresD dataset. The hourly time series of measured air temperature were extrapolated across the model domain to different elevations with a temperature lapse rate of $-5.5^{\circ} \mathrm{C} \mathrm{km}^{-1}$. Cloud cover transmissivity was derived from the hourly sunshine duration measurements following the empirical relation proposed by Kasten and Czeplak (1980).

The model was run at a $\Delta x=100 \mathrm{~m}$ spatial resolution and a constant time step $\Delta t=1 \mathrm{~h}$. To initiate the model calibration, realistic values of the hydrological parameters were assigned based on the soil characteristics and previous investigations (Paschalis et al., 2014; Pappas et al., 2015). The soil hydraulic conductivity and the residual and saturation soil water content parameters were then adjusted in order to maximize the performance of the hydrological model in terms of correlation coefficient $(r)$, Nash-Sutcliffe efficiency (NSE), and root mean square error (RMSE) for discharge measured at three streamflow gauging stations.

The final configuration of the hydrological model performed very well in reproducing the observed discharge at the outlet and at Werthenstein (see Table 1 and Fig. 2). Discharge data are available at a sub-daily resolution at Sörenberg only from the year 2005; therefore, the evaluation of the performance at this station does not consider the first year of simulation. The model performance at this station is slightly worse, probably also due to the lower accuracy of the measurements, but still satisfactory.

\subsubsection{Setup of the sediment module}

The inputs needed to run the hillslope erosion and suspended sediment transport modules are the parameters $\alpha, \beta$, and $\gamma$ in Eq. (2). The $\beta$ and $\gamma$ parameters are assumed spatially uniform and equal to 1.4 , following Prosser and Rustomji (2000). The parameter $\alpha$ contains information about 


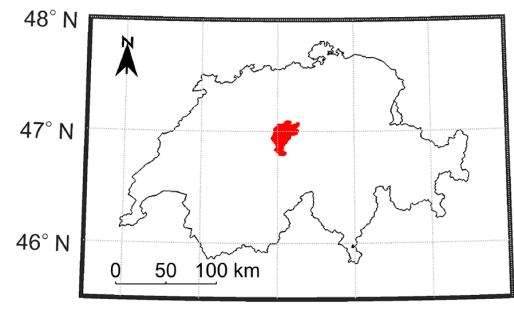

$6^{\circ} \mathrm{E} \quad 7^{\circ} \mathrm{E} \quad 8^{\circ} \mathrm{E} \quad 9^{\circ} \mathrm{E} \quad 10^{\circ} \mathrm{E} \quad 11^{\circ} \mathrm{E}$

(b)

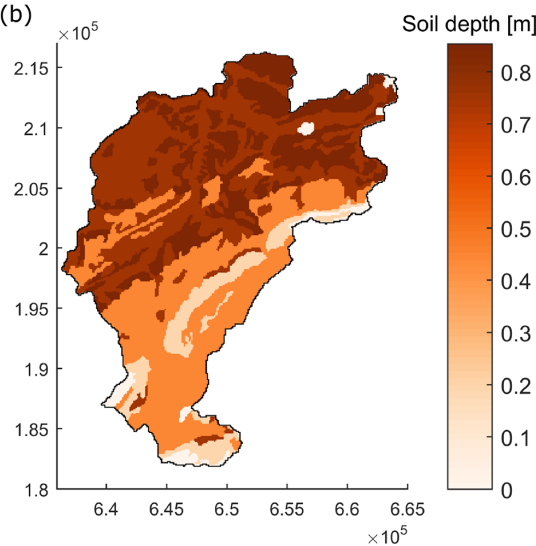

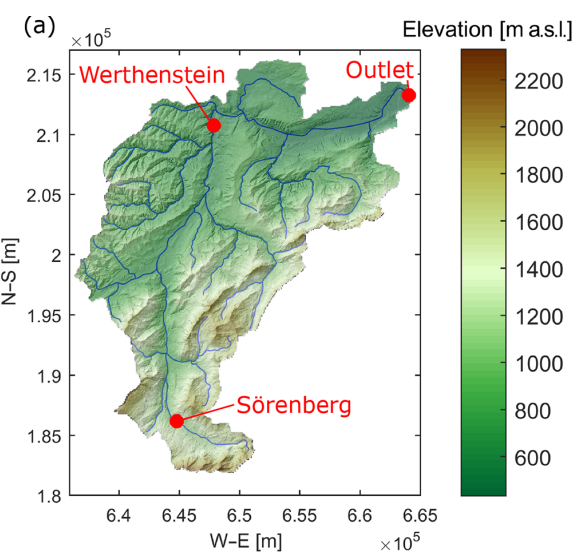

(c)

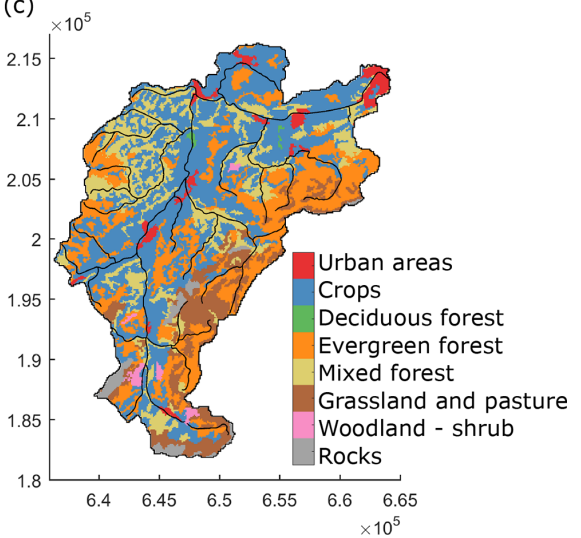

Figure 1. (a) Digital elevation model (DEM) of the Kleine Emme basin and location of discharge gauges (source SwissAlti3D, 2017), (b) soil depth, derived from the Swiss soil map (Bodeneignungskarte, 2012), and (c) land cover derived from Corine Land Cover map (CLC, 2014). The coordinate system is $\mathrm{CH} 1903$.

Table 1. Hydrological performance for the simulation period 2004-2016 at the three flow monitoring stations in terms of correlation coefficient $(r)$, Nash-Sutcliffe efficiency (NSE), and root mean square error (RMSE) for data simulated at the hourly resolution and aggregated to daily, monthly, and annual values.

\begin{tabular}{lrrr|rrr|rrr}
\hline & \multicolumn{3}{c|}{ Outlet } & \multicolumn{3}{c|}{ Werthenstein } & \multicolumn{3}{|c}{ Sörenberg (2005-2016) } \\
\cline { 2 - 10 } & $\begin{array}{r}r \\
(-)\end{array}$ & $\begin{array}{r}\text { NSE } \\
(-)\end{array}$ & $\begin{array}{r}\text { RMSE } \\
\left(\mathrm{m}^{3} \mathrm{~s}^{-1}\right)\end{array}$ & $\begin{array}{r}r \\
(-)\end{array}$ & $\begin{array}{r}\text { NSE } \\
(-)\end{array}$ & $\begin{array}{r}\text { RMSE } \\
\left(\mathrm{m}^{3} \mathrm{~s}^{-1}\right)\end{array}$ & $\begin{array}{r}r \\
(-)\end{array}$ & $\begin{array}{r}\text { NSE } \\
(-)\end{array}$ & $\begin{array}{r}\text { RMSE } \\
\left(\mathrm{m}^{3} \mathrm{~s}^{-1}\right)\end{array}$ \\
\hline Hour & 0.84 & 0.69 & 0.75 & 0.84 & 0.65 & 0.74 & 0.63 & 0.72 & 1.43 \\
Day & 0.91 & 0.80 & 0.53 & 0.90 & 0.78 & 0.52 & 0.80 & 0.56 & 0.83 \\
Month & 0.93 & 0.76 & 0.28 & 0.92 & 0.77 & 0.26 & 0.88 & 0.77 & 0.38 \\
Year & 0.93 & - & 0.18 & 0.92 & - & 0.13 & 0.79 & - & 0.10 \\
\hline
\end{tabular}

the soil and land surface properties that influence the rate of soil erosion. We derived the spatial distribution of $\alpha$ by the product of the soil erodibility parameter $K$ of the Universal Soil Loss equation (USLE), computed for Switzerland by Schmidt et al. (2018), and the land use USLE parameter $C$, which we derived from Yang et al. (2003) (see Fig. S1 in the Supplement). In this way we implicitly account for the influence of particle size distribution, organic matter content, soil structure, permeability, surface roughness, and vegetation cover in determining the spatial distribution of surface erodibility. A similar approach is proposed by Hancock et al. (2017).

The ratio between the product of $C$ and $K$ of the different classes was then kept constant in the calibration process, and $\alpha$ was calibrated by multiplying the $C K$ values by a spatially constant parameter $\alpha_{1}$ :

$\alpha(x, y)=\alpha_{1} C(x, y) K(x, y)$,

where $x$ and $y$ are coordinates in space. With respect to channel processes, the water column-bed exchange and local sed- 


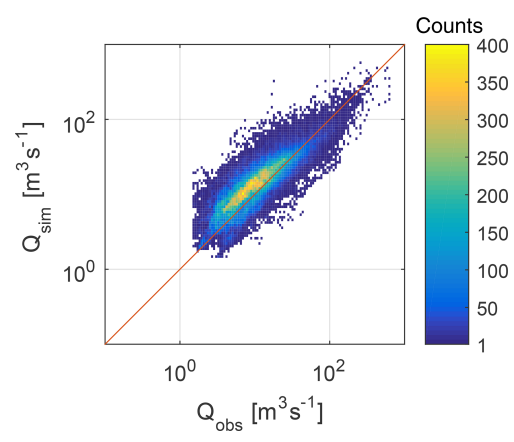

Figure 2. Performance of the hydrological model: density plot of observed vs. simulated hourly discharges at the outlet of the river basin for the period 2004-2016.

iment source term $E$ in Eq. (3) is unknown. In the Kleine Emme significant deposits of fine sediment in the river bed are not present, and bedrock is often exposed, indicating an efficient transport of fines downstream (Schwab et al., 2008). Furthermore, the infrequent SSC measurements do not allow us to quantify the term explicitly. This leads us to assume that $E=0$ for this river. However, by setting $E=0$ we also neglect local sediment sources along the channels, which is probably an approximation of the sediment production processes in this catchment. Also on the hillslopes, localized sediment sources are not explicitly modelled and are present only insofar they are represented by high $C$ and $K$ values. The lack of explicit inclusion of point sediment sources and their modelling is a limitation of the current approach, which we will address in future work.

\subsubsection{Calibration of the sediment module}

We found that the parameters that have the highest influence on matching the observed and simulated SSC at the outlet are the river initiation threshold RT, i.e. the extension of the modelled river network, and the $\alpha_{1}$ constant, defining the soil erodibility. RT has a small influence on discharge, as shown by Table $\mathrm{S} 2$, while it is a relevant parameter for the modelling of hillslope erosion and sediment transport. Since fine sediment mobilization can only take place on the hillslopes, the extension of the channels onto the hillslopes influences the magnitude of the sediment input into first-order channels and subsequently downstream through the river network.

In the calibration of the model we focused on measurements below the 85th percentile, because flood events in the SSC data are likely undersampled, due to the monitoring strategy, and the model is expected to underestimate the SSC extremes due to the simplified representation of the sediment mobilization processes. The calibration was performed by matching the trend and the dispersion of the measured and modelled SSC- $Q$ cloud of points. This was done by visual matching and by comparing the mean and variance in the observed SSCs. The final calibrated parameters are $\alpha_{1}=$
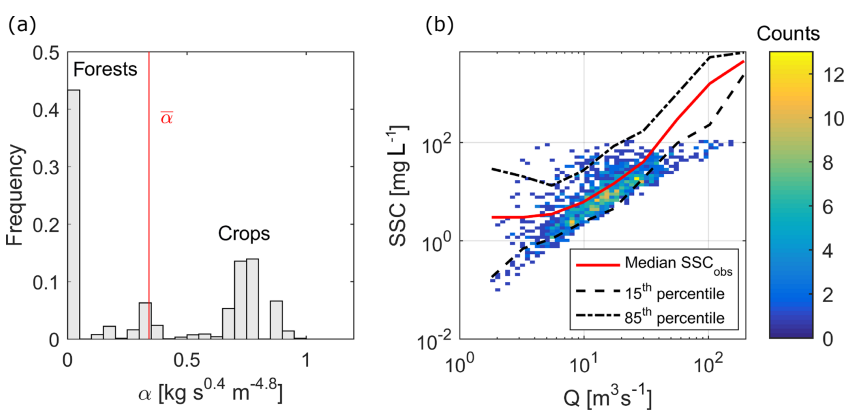

Figure 3. (a) Frequency distribution of the calibrated surface erodibility parameter $\alpha$, with mean $\alpha$ indicated with the red line; (b) density plot of the simulated SSC at outlet compared with measurements; the lines show the median (red) and 15th and 85th percentile (black dashed) of the observations.

$0.0138 \mathrm{~kg} \mathrm{~m}^{-1.8} \mathrm{~s}^{-2.6}$ and RT $=0.4 \mathrm{~km}^{2}$. The histogram of $\alpha$ and its spatial distribution are shown in Figs. $3 \mathrm{a}$ and $7 \mathrm{~d}$, respectively; the spatial mean of $\alpha$ is $0.3412 \mathrm{~kg} \mathrm{~s}^{0.4} \mathrm{~m}^{-4.8}$. We note that the calibrated river initiation threshold is very close to the drainage area that Schlunegger and Schneider (2005) propose as the threshold area at which channelized processes start dominating over hillslope processes in the development of the landscape in this study basin $\left(0.1-0.2 \mathrm{~km}^{2}\right)$.

Using this parameterization, the measured SSC $-Q$ cloud of points is captured very well for moderate discharges (Fig. 3b), whereas the concentrations at highest discharges are underestimated, as expected. Overall, $90.4 \%$ of the simulated SSCs fall within the 5th and 95th percentile of the observations, and, if the simulated SSCs are sampled at the hours of observations and compared to the observations limited to their 85th percentile, the observed SSC mean and variance are reproduced with very small errors $\left(\overline{\mathrm{SSC}}_{\mathrm{sim}}=12.40 \mathrm{mg} \mathrm{L}^{-1}, \overline{\mathrm{SSC}}_{\mathrm{obs}}=12.20 \mathrm{mg} \mathrm{L}^{-1} ; \sigma_{\mathrm{sim}}^{2}=\right.$ $210.47 \mathrm{mg} \mathrm{L}^{-1}, \sigma_{\mathrm{obs}}^{2}=233.15 \mathrm{mg} \mathrm{L}^{-1}$ ) (Fig. S2). We attribute the underestimation of high sediment concentrations (above 85 th percentile) to missing localized sediment sources, i.e. mass wasting processes in the model, which are responsible for point sediment sources, like landslides, debris flows, and bank erosion. Further evaluation of the suspended sediment module performance can be found in Table $\mathrm{S} 1$ and Fig. S3.

\section{Erosion driver numerical experiments}

In order to investigate the processes leading to the scatter in the $\mathrm{SSC}-Q$ relation and how they affect the spatial organization of sediment transport, we performed simulation experiments that quantify the role of spatial variability in two key erosion drivers - precipitation and surface erodibility. Precipitation is the main hydrological driver of hillslope erosion through the overland flow term $q^{\beta}$ in Eq. (2), while surface erodibility is represented by the parameter $\alpha$ in Eq. (2). 

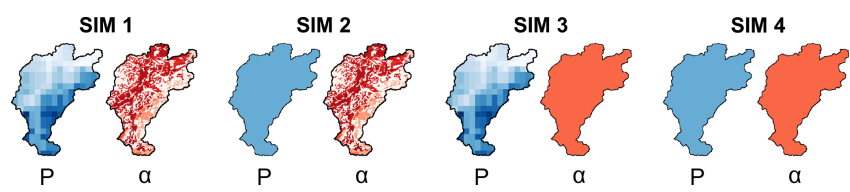

Figure 4. Summary of model runs: in SIM 1 sediment mobilization and transfer are driven by a spatially distributed precipitation $(P)$ and surface erodibility $(\alpha)$; in SIM 2 and SIM 3 the spatial variability in precipitation and surface erodibility have been removed, respectively; and in SIM 4 both spatial variabilities have been removed.

We designed four numerical experiments by combining spatially variable and/or uniform distributions of the two erosion drivers (Fig. 4). The reference experiment (SIM 1) accounts for the highest level of complexity by considering both precipitation and erodibility variable in space. This is the experiment with which the model was calibrated (see Sect. 2.3.3). The second experiment (SIM 2) aims to quantify the role of the spatial variability in precipitation, by reducing it to be uniformly distributed in space. The temporal variability was preserved by setting the hourly precipitation in each cell equal to the mean hourly precipitation over the catchment. The third experiment (SIM 3) is designed to investigate the role of the spatial variability in surface erodibility by reducing it to uniform surface erodibility throughout the basin, equal to the mean value of the calibrated spatial distribution of $\alpha$. A fourth experiment (SIM 4), where the spatial variability in both drivers was reduced to uniform, was run to quantify the combined effect of the two erosion drivers.

\section{Results}

In Sect. 4.1 we evaluate the spatio-temporal variability in sediment mobilization and transport and the scatter of the SSC $-Q$ relation it produces by the fully distributed erosion drivers in SIM 1 (RQ1). The spatial distribution of suspended sediment transport is then evaluated in subsequent sections and related to the hydrological response of the basin (RQ2). We compare the activation of sediment sources and the sediment mobilization in the four simulations (Sect. 4.2), and we quantify the connectivity of sediment transfer by means of the sediment delivery ratio (Sect. 4.3). Finally, in Sect. 4.4, we analyse the sediment load at the outlet as a function of the sediment spatial properties observed in the different scenarios (RQ3).

\subsection{Spatio-temporal variability in erosion and sediment transport}

The modelled scatter in the SSC $-Q$ relation in SIM 1 explains about $30 \%$ of the measured concentration range for discharges up to the 85th percentile, while it shows a much more significant underestimation for the highest flows
(Fig. 3b). For a comparison between the SSC $-Q$ scatter generated by the different scenarios of erosion drivers, the reader is referred to Figs. S5 and S6. In the following we analyse the sources of this variability, by showing the time series of discharge and the sediment load and concentration for 1 representative year (Fig. 5a) and by analysing the pattern of erosion and deposition across the basin from the entire simulation period (Fig. 5b).

High sediment fluxes in April and May, which are evident both in observations and in the model (Fig. 5), indicate the contribution of snowmelt to discharge and the erosion of the surface by widespread overland flow. Summer events (storms) provide a small contribution to the yearly sediment yield. However, they generate some of the highest sediment concentrations in the model even though the runoff remains low. As expected, high SSCs are not observed in the measurements during summer, because sediment is rarely sampled during summer floods (see Sect. 2.2). In winter months, snow covers the majority of the catchment and maintains the sediment flux very close to zero in both observations and simulations (Fig. 5a).

Most of the erosion is simulated in the south-eastern part of the basin, where slopes are steeper, soil is thinner, and the highest precipitation, snow accumulation, and melt occur (Fig. 5b). In these regions, it is easier to saturate the soil and generate runoff over larger areas that merge and generate connected areas of overland flow, thus producing wide erosional surfaces on steep mountain flanks. Deposition is simulated at the valley bottoms or at locations of slope reduction. In the north-western part of the basin, overland flow remains constrained to the channel headwaters due to the deeper soil and to the higher drainage density of the area. This distribution of erosion is coherent with the different geomorphological characteristics of the two areas of the basin, as further discussed in Sect. 5.2. We observe that, because of the transport capacity approach in the hillslope transport module, areas of strong erosion are often associated with significant deposition downstream. In the following, we will refer to these areas of strong erosion as sediment source areas.

The mean annual suspended sediment load generated by SIM 1 is $1.42 \times 10^{4} \mathrm{tyr}^{-1}$, which is significantly lower than the $2.83 \times 10^{5} \mathrm{t} \mathrm{yr}^{-1}$ computed from the measurements at Littau by Hinderer et al. (2013). Consistently, the mean annual erosion rate of $0.07 \mathrm{~mm} \mathrm{yr}^{-1}$ underestimates the denudation rates derived from ${ }^{10} \mathrm{Be}$ samples in the Entlen and Fontanne subbasins by Wittmann et al. (2007), Norton et al. (2008), and Van Den Berg et al. (2012) (between 0.38 and $0.52 \mathrm{~mm} \mathrm{yr}^{-1}$ ), which are from active erosion areas and integrate over a much longer time span of about $10^{4}$ years. The lower estimates of sediment load and erosion rates by our model compared to such data are expected, given the underestimation of SSC at high flows by the model. This limitation will be further discussed in Sect. 5.1. 
(a)
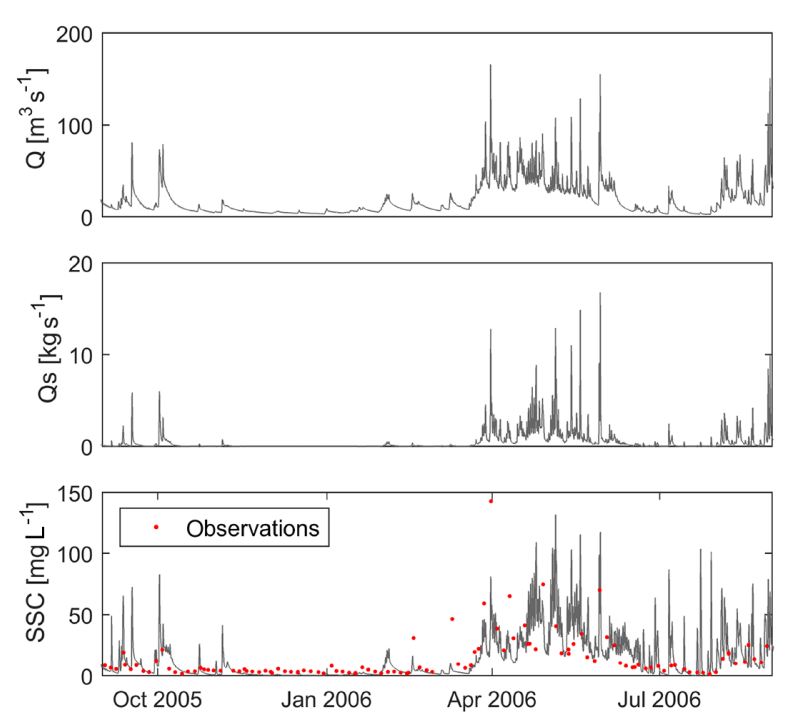

(b)

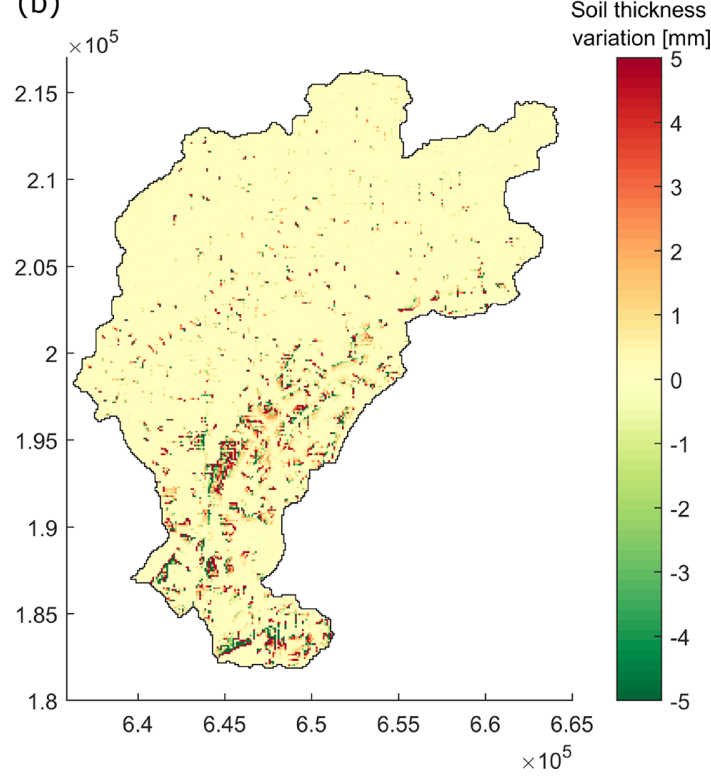

Figure 5. (a) Time series of hourly modelled discharge $Q$, suspended sediment load $Q_{\mathrm{s}}$, and concentrations SSC for 1 year at the outlet. The red dots in the SSC time plot show the observed values. (b) Change in soil thickness at the end of the 13-year simulation. Positive values indicate erosion, while negative values indicate deposition.

\subsection{Sediment sources and sediment production}

To interpret the effect of the spatial variability in precipitation and surface erodibility on sediment transport, in Fig. 6 we compare the hydrological response of the basin in the four simulations in terms of the mean annual discharge $Q_{\text {mean }}$, annual flood $Q_{\max }$, coefficient of variation $\mathrm{CV}$ of the hourly discharge at the basin outlet, and mean annual overland flow runoff over the basin $Q_{\mathrm{OF} \text { mean }}$. Figure 6 indicates that uniform precipitation (SIM 2 and 4) is less efficient in producing runoff ( $Q_{\text {mean }}, Q_{\max }$, and $\left.Q_{\mathrm{OF} \text { mean }}\right)$ and therefore has a lower erosive power. Spatially variable precipitation (SIM 1 and 3) produces a greater flow variability, because it distinguishes between convective rainfall patterns, which affect smaller regions of the basin, and stratiform rainfall patterns, which affect the entire basin with lower precipitation intensities.

The sediment response of the basin in the four simulations is compared in the following by looking at the distribution of sediment source areas and their productivity. Figure 7 compares soil thickness variation in SIM 2 and 3 to SIM 1. Figure $7 \mathrm{~b}$ and $\mathrm{c}$ show the difference between the variable and uniform precipitation maps for erosion and deposition, respectively. Similarly, Fig. 7e and f show the difference between the variable and uniform surface erodibility maps for erosion and deposition separately. A positive value indicates more erosion/less deposition by variable precipitation or surface erodibility, and a negative value indicates less erosion/more deposition.

The results show that with uniform precipitation, erosion and deposition are reduced in the south-eastern part of the basin and increased in the north-western (Fig. 7b and c). The overall patterns reflect the average spatial distribution of precipitation in the Kleine Emme catchment for the years 20042016, with the highest mean rain intensities associated with more erosion (Fig. 7a). Uniform surface erodibility increases sediment erosion and deposition in the forested areas and reduces them in crop areas (Fig. 7e and f). In both cases, the overall effect of removing the spatial variability in erosion drivers is a more uniform distribution of the sediment source areas across the basin.

To quantify the erosional power of the four combinations of erosion drivers, we computed the total sediment mass detached yearly across the whole basin (referred to as sediment production) in the four simulations. The distribution of the yearly sediment production with interannual variability is reported in Fig. 8. We observe that the removal of spatial variability generates two opposite effects for precipitation and surface erodibility. Sediment production increases when removing the spatial variability in surface erodibility and decreases when removing the spatial variability in precipitation, coherently with the reduced erosive power observed in Fig. 6. In SIM 4 the balance between the two opposing effects determines a slight overall reduction in sediment production. The differences between the scenarios are within natural interannual variability in sediment production, but they are all statistically significant for change in median. 
(a)

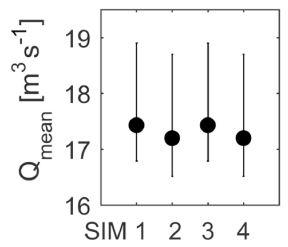

(b)

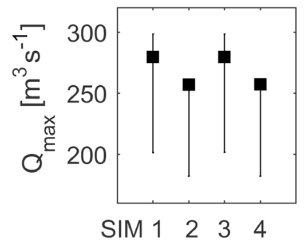

(c)

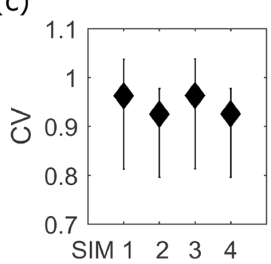

(d)

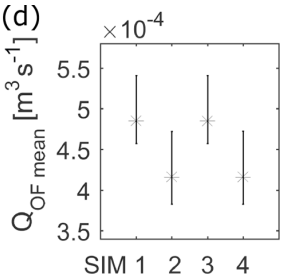

Figure 6. Comparison of the hydrological response of the basin in the four simulations: (a) mean annual discharge $Q_{\text {mean }}$, (b) annual flood $Q_{\max }$, (c) coefficient of variation CV of the hourly discharge at the basin outlet, and (d) mean annual overland flow runoff over the basin $Q_{\mathrm{OF} \text { mean }}$. Markers indicate mean values and the lines the interval between the 25 th and 75 th percentile of the distribution from hourly data over the entire simulation period.
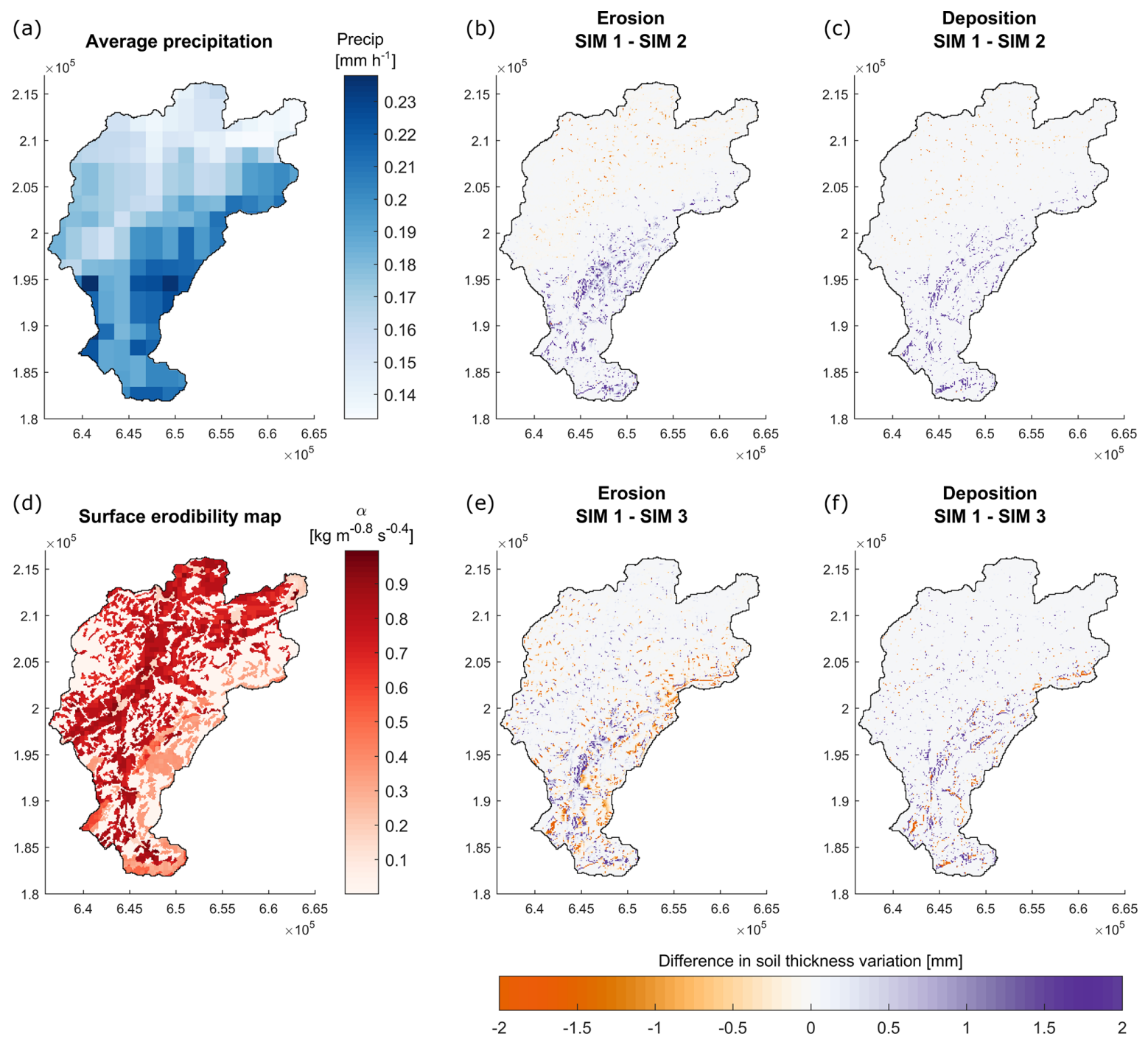

Figure 7. (a) Average spatial distribution of precipitation intensity for the period 2004-2016; (b, c) difference between erosion/deposition generated by variable and uniform rainfall in 13 years; (d) spatial distribution of calibrated surface erodibility $\alpha$; (e, f) difference between erosion/deposition generated by variable and uniform surface erodibility in 13 years. A positive value indicates more erosion/less deposition by variable precipitation or surface erodibility, and a negative value indicates less erosion/more deposition. 


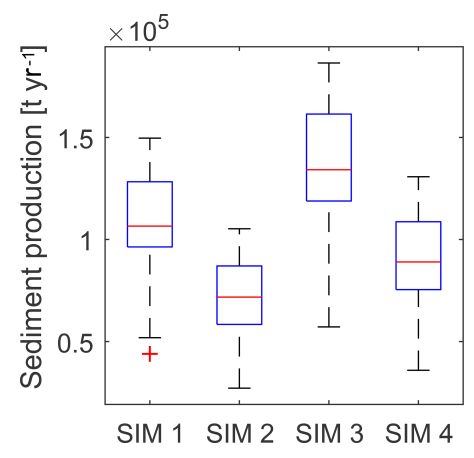

Figure 8. Sediment production in the basin as total sediment detached annually for the four simulations. Boxplots (median, interquartile range, and outliers) show the interannual variability in the period 2004-2016.

\subsection{Connectivity of sediment transfer}

The connectivity of sediment transfer, i.e sediment source areas linked to the river network, within the catchment for the different simulation configurations has been quantified by means of the sediment delivery ratio (SDR). The SDR is defined according to Walling (1983) as the ratio of the sediment delivered at the outlet of a selected area to the gross erosion in that area. The mean annual SDRs, which were computed at the outlet point of the main tributaries and at several cross sections along the main channel, are reported in Fig. 9 as a function of the drainage area.

Sediment connectivity along the main channel shows an increasing trend as a function of the upstream area for all simulations (Fig. 9c). This trend is explained by the higher SDR of the tributaries compared to that of the main channel (Fig. 9b) and by the absence of significant sediment sinks in the main channel. For the subbasins with outlets along the main channel, removing the spatial variability in surface erodibility (SIM 3) has the overall effect to increase sediment connectivity. In some tributaries, however, the opposite effect is observed (T5 and T6). Finally, Fig. 9c shows that removing the spatial variability in precipitation (SIM 2 and 4) also increases the SDR and therefore sediment connectivity (compared to SIM 1 and 3, respectively).

\subsection{Sediment loads and initial soil moisture}

The distribution of annual sediment yields at the outlet generated by the four simulation experiments showed that distributed precipitation simulations (SIM 1 and 3) generated higher sediment loads than their uniform precipitation equivalents (SIM 2 and 4) (Fig. 10a). Distributed erodibility (SIM 1 and 2) produced smaller sediment loads than uniform erodibility (SIM 3 and 4).

To further investigate the differences among the sediment yield distributions, in Fig. 10b we show the influence of spatial variability in rainfall and surface erodibility on event- based sediment yields for high and low initial soil moisture $\left(\mathrm{SM}_{0}\right)$ conditions. After separating the outlet hydrograph into single events, we computed the total sediment yields for each event and compared the distributions of the events with high and low initial soil moisture. Low-SM $\mathrm{SM}_{0}$ events are defined as those with catchment-averaged $\mathrm{SM}_{0}$ smaller than the 20th percentile of the $\mathrm{SM}_{0}$ distribution; high-SM $\mathrm{SM}_{0}$ events have a $\mathrm{SM}_{0}$ greater than the 80 th percentile. The hydrological model performance for these events is good and comparable to the entire simulation performance; however it indicates a tendency to overestimate especially for low $\mathrm{SM}_{0}$ events (see Table S3 and Fig. S4).

The distributions of event sediment yields largely overlap; however it is possible to observe that sediment yield is more affected by the precipitation spatial variability when $\mathrm{SM}_{0}$ is low. The differences between the median and 25th and 75th percentile of the SIM 1 and 2 are greater for low $\mathrm{SM}_{0}$ than for high $\mathrm{SM}_{0}$. On the contrary, removing variability in surface erodibility seems to equally affect low and high initial $\mathrm{SM}_{0}$ events (Fig. 10b).

\section{Discussion}

\subsection{Sources of concentration variability}

The modelling approach presented here can reproduce part of the observed SSC $-Q$ scatter, implying that it contains some of the relevant sources of sediment concentration variability in the hydrological and sediment production processes at the catchment scale (Fig. 3b). However, it also highlights that to fully capture the scatter, other sources should be included. The comparison of simulated and observed hourly SSC is satisfactory (Fig. S3).

The sources of variability accounted for by the deterministic modelling of the hydrology and sediment transfer are the time-varying meteorological inputs and the spatially distributed nature of the model. The precipitation input combines both temporal and spatial components of variability. The temporal component is visible in Fig. 5a, showing that the same sediment concentration can correspond to a large range of discharge values, depending on the type of event and the initial soil wetness conditions that precede it. Spatial variability in precipitation contributes to the $\mathrm{SSC}-Q$ scatter, by increasing the flow variability itself (Fig. 6c) and by allowing the same discharge at the outlet to be generated by many combinations of overland flow situations over the hillslopes. Each of these combinations activates different sediment sources that have a characteristic hydrological and sediment signal and connectivity to the river network. In particular, we identify localized high-intensity summer storms as a main source of scatter, while snowmelt and winter storms produce a more homogeneous response throughout the basin. The spatially variable surface erodibility can additionally contribute to the uniqueness of the sediment signals of the 
(b)

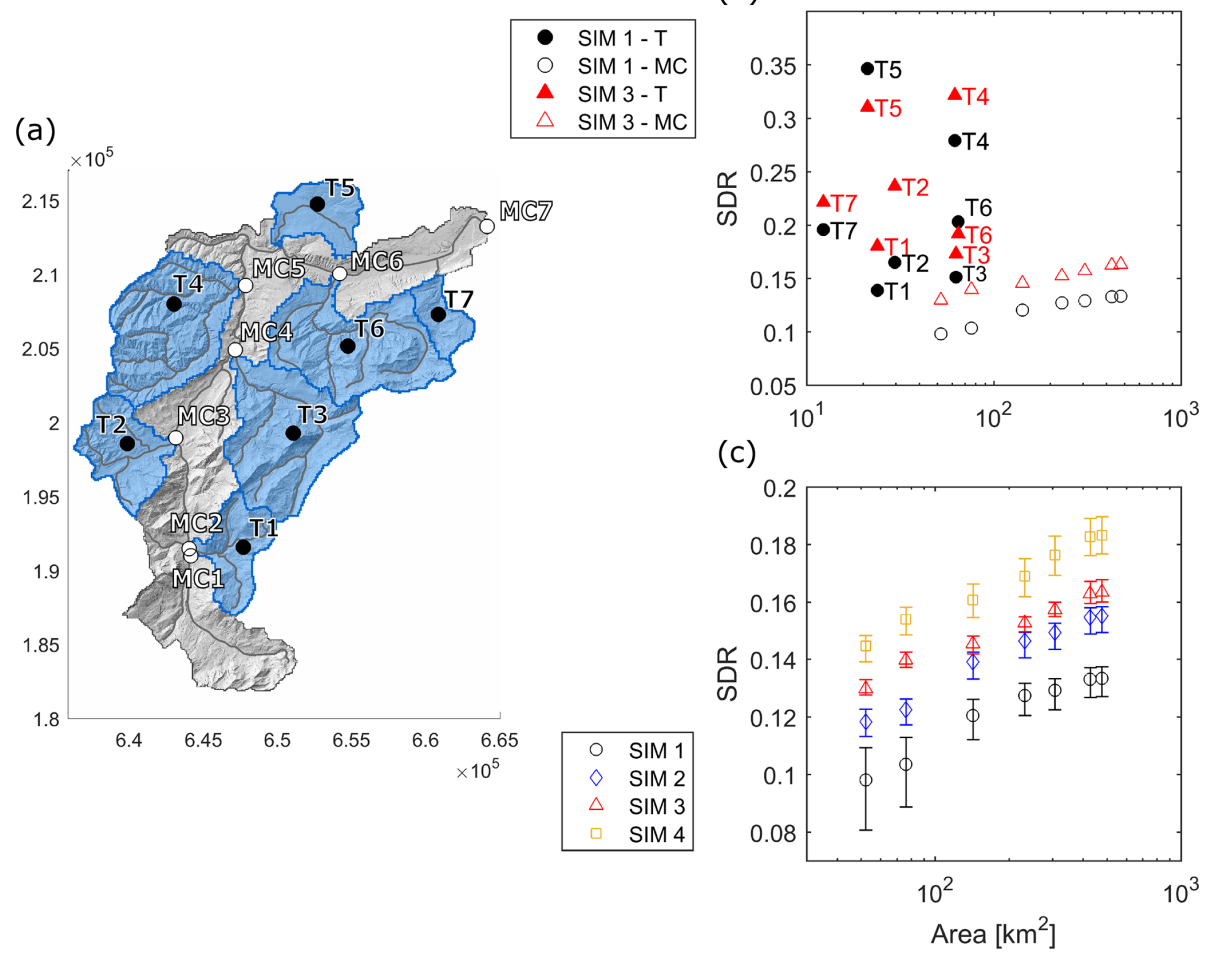

Figure 9. (a) Locations where the sediment delivery ratio has been computed: at the outlet of the main tributaries (T) and along the main channel (MC); (b) mean annual SDR vs. drainage area for tributaries and points along the main channel for distributed rainfall simulations; (c) comparison of mean annual SDRs at the main channel points for the four simulations. The error bars show the interquartile range of the annual SDR variability.
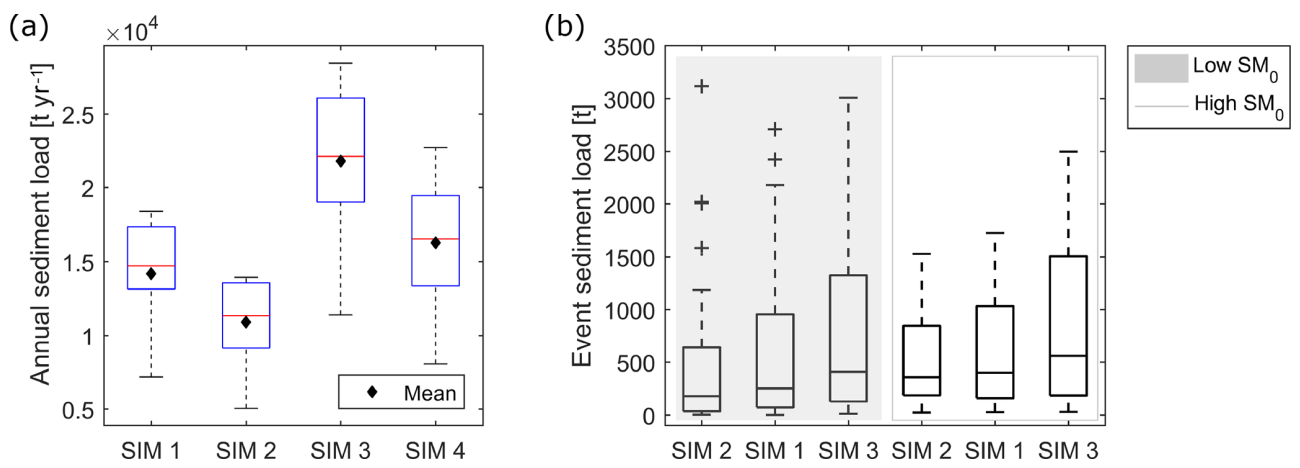

Figure 10. (a) Boxplots of annual sediment load and their mean values at the outlet of the catchment in the four simulation experiments; (b) boxplots of event sediment loads divided into low and high initial soil moisture conditions. The boxplots compare the effect of the spatial variability in precipitation and surface erodibility on events with different initial soil moisture.

activated source areas, when its spatial distribution is such to enhance the topographic heterogeneity within the basin.

Other sources of variability in sediment transport are implicit in the spatially distributed nature of the model, which allows one to account for the heterogeneity of topography, soil depth, and soil properties at very high resolution. These heterogeneities are responsible for the residual scatter of SIM 4, where the variability in both erosion drivers have been removed.
It is worth noting that, because the sediment storage on hillslope cells is not exhausted during our simulation experiments, sediment availability does not influence sediment production in our study. Therefore, sediment availability in the simulation experiments does not drive changes in the dominant sediment sources and does not add spatial variability to the sediment response.

The main limitation of our approach in reproducing SSC variability is, however, the lack of processes representing 
very localized sediment sources, which are usually characterized by a threshold behaviour and therefore diversify the local sediment response. In this respect, Schwab et al. (2008) showed that in the Kleine Emme basin short timescale threshold processes are responsible for the export of regolith produced by soil creep in landslides. The absence of these processes in our model is likely one of the main reasons not only for the smaller-than-observed modelled SSC- $Q$ scatter but also for the underestimation of the highest SSCs, the soil erosion rate, and annual sediment load, presented in Sect. 4.1. Finally, we acknowledge that inherent stochasticity in the sediment mobilization and transfer are also responsible for part of the observed SSC $-Q$ rating curve scatter (e.g. Fuller et al., 2003; Malmon et al., 2003). This inherent stochasticity cannot be reproduced by our modelling approach with deterministic simulation, but it can be included with stochastic simulation experiments and a probabilistic framework (e.g. Bennett et al., 2014). We are working on overcoming these limitations in future research.

\subsection{Spatial organization of suspended sediment transport}

The explicit combination of hydrological processes and topographic and land use effects in the model can help to investigate the spatial organization of sediment transport and, in particular, how this is affected by the spatial variability in erosion drivers. Spatial variability enhances the heterogeneity of erosion and deposition across the catchment, thus favouring the clustering of sediment source areas (Fig. 7). Sediment production is increased by the spatially variable precipitation (SIM 1 and SIM 3), due to increased erosive power (Fig. 8). The effect of a spatially variable surface erodibility depends on the distribution of overland flow relative to that of surface erodibility, and, in this case, the lower sediment productions of SIM 1 and 2 (Fig. 8) indicate that the two distributions combine more intense overland flow with lower erodibility areas, thus reducing the overall sediment production.

In Fig. 9 we use the modelled SDR as a measure of sediment transfer connectivity, as it quantifies the proportion of mobilized sediment that is routed to the outlet of a selected subbasin by action of overland and channel flow. As such, the modelled SDR can be seen as a dynamic indicator of functional connectivity, where the discharge is represented explicitly in time and space as a function of the hydrological forcings and topographic characteristics, as opposed to the widely used approximation as a function of the upstream area. In this way, our approach integrates the variability in functional connectivity both in time and space. A similar approach to dynamically quantify functional connectivity has been proposed by Mahoney et al. (2018), which is also based on hydrological modelling.

The sediment delivery ratio shows that the connectivity of sediment sources is reduced by the spatial variability in precipitation, and this effect can be explained by the geomorphic connectivity of the catchment. Higher precipitation, shallower soils, and steeper slopes in the south-eastern region of the basin, i.e. tributaries T1, T3, and T6 and the upper stretch of the main channel (see Fig. 9a), favour overland flow generation and thus hydrological connectivity. However, the lower topographic connectivity of these subbasins overall causes a reduction in the sediment transfer connectivity. Such lower connectivity is indicated by the low SDRs of these subbasins in SIM 3, which does not account for the land use effect, and suggests the presence of geomorphic sediment buffers (Fryirs, 2013). The different topographic connectivity of the south-eastern and north-western regions reflects the different geomorphology of these two parts of the basin. In fact, the south-eastern region of the basin is characterized by a predominantly Last Glacial Maximum landscape with wide valleys and major instabilities, which are in most cases not directly connected to the river network (Schwab et al., 2008; Van Den Berg et al., 2012; Clapuyt et al., 2019). On the other hand, the north-western part of the basin, i.e. tributaries $\mathrm{T} 4$ and $\mathrm{T} 5$, shows a rejuvenating landscape where recent fluvial dissection created narrow and deeply incised valleys with a strong coupling between hillslopes and channels (Schlunegger and Schneider, 2005; Norton et al., 2008).

The reduction of sediment transfer connectivity by spatially distributed surface erodibility can be attributed to the assumption in the sediment module that the sediment discharge always satisfies the overland flow transport capacity. Based on this assumption, a spatially variable $\alpha$ allows one, on the one hand, to modulate the sediment mobilization in space and, on the other hand, to define preferential areas of sediment deposition and therefore sediment connectivity. By attributing a lower transport capacity to forests, their role as sediment buffers blocking sediments will emerge. Vice versa, high $\alpha$ values in crop areas will mean the absence of obstacles to sediment flux. Therefore, the smaller sediment transfer connectivity of SIM 1 and 2 compared to SIM 3 and 4 reflects the location of sediment buffers (i.e. forests) with respect to the channel network. In fact, in most of the basin, forested areas surround channel headwaters, thus disconnecting the sediment sources on the hillslopes and mountain flanks from the river network (see e.g. Clinnick, 1985; Parkyn et al., 2005; Schoonover et al., 2006; Mekonnen et al., 2015).

\subsection{Sediment load and connectivity}

The analyses presented in the previous sections focus on the driving processes of sediment mobilization and transfer across the basin and the reasons for the reduction in SDR with variable erosion drivers. In this section we analyse how their balance determines the sediment load at the outlet.

In the distributed surface erodibility simulations (SIM 1 and 2) a reduced sediment yield $(Y)$ is observed at the basin outlet determined by a reduction in both sediment produc- 
tion $(P)$ and sediment transfer connectivity (expressed by the SDR) with respect to uniform erodibility simulations (SIM 3 and 4):

$$
\downarrow Y=\mathrm{SDR} \downarrow \cdot P \downarrow .
$$

In the distributed precipitation simulations (SIM 1 and 3), instead, an increased sediment yield at the basin outlet is observed compared to uniform precipitation simulations, which results from a combination of a smaller SDR and a much greater sediment production across the basin. The increase in sediment yield indicates that the greater sediment production dominates over the decreased sediment connectivity:

$$
\uparrow Y=\operatorname{SDR} \downarrow \cdot P \Uparrow .
$$

This result means that localized sediment source areas are activated by the very high erosive power of localized precipitation captured by distributed simulations. Their signal reaches the outlet despite the system being globally less efficient in evacuating the eroded sediments. These hotspots of erosion are generated where precipitation falls with a high intensity, soil saturation is reached soon during storms, eventually favoured by shallow soils, and therefore hydrological and sediment flux connectivity are locally high.

In a hydrological modelling experiment conducted with TOPKAPI-ETH on the same catchment, Paschalis et al. (2014) demonstrated the dependence of the discharge peak on the clustering of high soil moisture areas. Our results show that the high soil moisture areas may also define the sediment signal. This finding also suggests that a large proportion of the sediment yield can be supplied by just few localized sediment sources (e.g. Pelletier, 2012). The role of soil moisture in producing high sediment concentrations has also been highlighted by Dominic et al. (2015) and Brasington and Richards (2000), who attribute the peaks of SSCs to the connection of remote sediment sources during the wetting up of a catchment.

Given the relevance of soil moisture spatial distribution for runoff generation, we also expect event sediment yields to be more affected by precipitation spatial variability, i.e. precipitation intensity, at low initial soil moisture than at high initial soil moisture, as is suggested by Fig. 10b. This is further supported by findings of Paschalis et al. (2014) and Shah et al. (1996) which indicate that higher initial basin saturation reduces the dependency of runoff on precipitation spatial distribution. However, we also stress that in our study the relatively small difference between the sediment load distributions of low- and high-SM $\mathrm{S}_{0}$ events and the tendency to overestimate flow in low $\mathrm{SM}_{0}$ events do not allow for a clear conclusion.

\section{Conclusions}

We presented a new spatially distributed soil erosion and suspended sediment transport module integrated into the computationally efficient physically based hydrological model
TOPKAPI-ETH. The model allows for continuous longterm, high temporal and spatial resolution simulations of erosion and sediment transport in mesoscale basins, and it is based on the physically driven processes of overland flow on hillslope and in channels. With the aim of exploring the impacts of two key spatially variable erosion drivers on suspended sediment dynamics, we conducted a series of numerical experiments on a mesoscale river basin. We compared the effects of spatially variable rainfall and surface erodibility with combinations of uniform and variable spatial distributions of these drivers.

Our results show that, first, the proposed model can reproduce part of the scatter of the observed $\mathrm{SSC}-Q$ relation, which is generated by spatially and temporally variable meteorological inputs and spatial heterogeneities of the physical properties of the basin, leading to a multitude of possible flow and sediment pathways. At the same time, our results suggest that other processes are also relevant to capture the scatter, such as localized sediment sources and the inherent randomness of sediment production and transfer, which are not included in our model.

Second, we found that spatial variability in both drivers favours the clustering of sediment source areas and reduces their overall connectivity to the river network, by capturing the buffering effect of forests and low-slope areas. At the same time, spatially variable surface erodibility reduces sediment production, while a spatially variable precipitation increases sediment production by high rates of erosion in areas of high rainfall and overland flow intensity.

Third, we found that the combination of the effects of spatial variability on sediment production and connectivity determines an overall lower sediment yield for distributed surface erodibility, due to reduced sediment production and to buffering effects, and a greater sediment yield for distributed precipitation, due to locally very high soil erosion. This last result is due to areas of high soil moisture in the catchment that are easy to saturate, which produce high local sediment inputs and catchment loads in spatially variable simulations.

Although our findings were obtained with reference to the specific climatic and geomorphologic features of the Kleine Emme catchment, we think they indicate the general importance of resolving the spatial variability in sediment mobilization and transfer processes when modelling sediment dynamics at the basin scale. The model we presented is particularly suitable for applications at medium and large scales, where gradients in climatic and physiographic characteristics represent a key control on sediment mobilization and transfer. Moreover, this model offers a valuable tool for investigating future scenarios of precipitation and land cover, which are expected to take place due to climate change or human land use management.

Data availability. DEM, soil and land use maps, discharge and suspended sediment concentration data, and simulation results are 
available at https://doi.org/10.3929/ethz-b-000358874 (Battista et al., 2019). Meteorological input data can be requested at https: //gate.meteoswiss.ch/idaweb/login.do (MeteoSwiss, 2019).

Supplement. The supplement related to this article is available online at: https://doi.org/10.5194/esurf-8-619-2020-supplement.

Author contributions. GB developed the model and carried out the simulations and the analyses of the results. PM and PB contributed to the conceptualization of the model and to the discussion of the results. GB prepared the paper with contributions and edits from all coauthors.

Competing interests. The authors declare that they have no conflict of interest.

Acknowledgements. We thank Fritz Schlunegger (University of Bern) for sharing his knowledge of the study basin and Enrico Weber (ETH Zurich) and Scott Sinclair (ETH Zurich) for technical support during the development of the model.

Financial support. This research has been supported by the DAFNE project, Horizon 2020 programme WATER 2015 of the European Union (grant no. 690268).

Review statement. This paper was edited by Greg Hancock and reviewed by two anonymous referees.

\section{References}

Asselman, N. E.: Suspended sediment dynamics in a large drainage basin: The River Rhine, Hydrol. Process., 13, 1437-1450, https://doi.org/10.1002/(SICI)10991085(199907)13:10<1437::AID-HYP821>3.0.CO;2-J, 1999.

Asselman, N. E.: Fitting and interpretation of sediment rating curves, J. Hydrol., 234, 228-248, https://doi.org/10.1016/S00221694(00)00253-5, 2000.

Battista, G., Molnar, P., and Burlando, P.: Model inputs and simulation results, ETH Zurich Research Collection, https://doi.org/10.3929/ethz-b-000358874, 2019.

Beasley, D. B., Huggins, L. F., and Monke, E. J.: ANSWERS: A Model for Watershed Planning, T. ASAE, 23, 0938-0944, https://doi.org/10.13031/2013.34692, 1980.

Bennett, G. L., Molnar, P., McArdell, B. W., and Burlando, P.: A probabilistic sediment cascade model of sediment transfer in the Illgraben, Water Resour. Res., 50, 1225-1244, https://doi.org/10.1002/2013WR013806, 2014.

Bilotta, G. S. and Brazier, R. E.: Understanding the influence of suspended solids on water quality and aquatic biota, Water Res., 42, 2849-2861, https://doi.org/10.1016/j.watres.2008.03.018, 2008.
Bodeneignungskarte: $\quad 77.2$ Digitale Bodeneignungskarte der Schweiz, available at: https://www.blw. admin.ch/blw/de/home/politik/datenmanagement/ geografisches-informationssystem-gis/download-geodaten.html (last access: 21 June 2018), 2012.

Borrelli, P., Robinson, D. A., Fleischer, L. R., Lugato, E., Ballabio, C., Alewell, C., Meusburger, K., Modugno, S., Schütt, B., Ferro, V., Bagarello, V., Oost, K. V., Montanarella, L., and Panagos, P.: An assessment of the global impact of 21st century land use change on soil erosion, Nat. Commun., 8, https://doi.org/10.1038/s41467-017-02142-7, 2017.

Bracken, L. J., Turnbull, L., Wainwright, J., and Bogaart, P.: Sediment connectivity: A framework for understanding sediment transfer at multiple scales, Earth Surf. Proc. Land., 40, 177-188, https://doi.org/10.1002/esp.3635, 2015.

Brasington, J. and Richards, K.: Turbidity and suspended sediment dynamics in small catchments in the Nepal Middle Hills, Hydrol. Process., 14, 2559-2574, https://doi.org/10.1002/10991085(20001015)14:14<2559::AID-HYP114>3.0.CO;2-E, 2000.

Chen, X. and Zong, Y.: Coastal Erosion Along the Changjiang Deltaic Shoreline, China: History and Prospective, Estuar. Coast. Shelf S., 46, 733-742, https://doi.org/10.1006/ecss.1997.0327, 1998.

Clapuyt, F., Vanacker, V., Christl, M., Van Oost, K., and Schlunegger, F.: Spatio-temporal dynamics of sediment transfer systems in landslide-prone Alpine catchments , Solid Earth, 10, 1489-1503, https://doi.org/10.5194/se-10-1489-2019, 2019.

CLC: Corine Land Cover (CLC) map 2012, available at: https: //land.copernicus.eu/pan-european/corine-land-cover/clc-2012 (last access: 18 January 2019), 2014.

Clinnick, P. F.: Buffer strip management in forest operations: A review, Aust. Forestry, 48, 34-45, https://doi.org/10.1080/00049158.1985.10674421, 1985.

Cohen, S., Kettner, A. J., Syvitski, J. P., and Fekete, B. M.: WBMsed, a distributed global-scale riverine sediment flux model: Model description and validation, Comput. Geosci., 53, 80-93, https://doi.org/10.1016/j.cageo.2011.08.011, 2013.

Collins, A. L. and Walling, D. E.: Progress in Physical Geography Documenting catchment suspended sediment sources : problems , approaches and prospects, Prog. Phys. Geogr., 2, 159-196, https://doi.org/10.1191/0309133304pp409ra, 2004.

Costa, A., Anghileri, D., and Molnar, P.: Hydroclimatic control on suspended sediment dynamics of a regulated Alpine catchment: a conceptual approach, Hydrol. Earth Syst. Sci., 22, 3421-3434, https://doi.org/10.5194/hess-22-3421-2018, 2018.

Coulthard, T. J., Neal, J. C., Bates, P. D., Ramirez, J., de Almeida, G. A., and Hancock, G. R.: Integrating the LISFLOOD-FP 2D hydrodynamic model with the CAESAR model: Implications for modelling landscape evolution, Earth Surf. Proc. Land., 38, 1897-1906, https://doi.org/10.1002/esp.3478, 2013.

Davies-Colley, R. J. and Smith, D. G.: Turbidity, suspended sediment, and water clarity: A review, J. Am. Water Resour. As., 37, 1085-1101, https://doi.org/10.1111/j.17521688.2001.tb03624.x, 2001.

Dominic, J. A., Aris, A. Z., and Sulaiman, W. N. A.: Factors Controlling the Suspended Sediment Yield During Rainfall Events of Dry and Wet Weather Conditions in A Tropical Urban Catchment, Water Resour. Manag., 29, 4519-4538, https://doi.org/10.1007/s11269-015-1073-0, 2015. 
Doten, C. O., Bowling, L. C., Lanini, J. S., Maurer, E. P., and Lettenmaier, D. P.: A spatially distributed model for the dynamic prediction of sediment erosion and transport in mountainous forested watersheds, Water Resour. Res., 42, 1-15, https://doi.org/10.1029/2004WR003829, 2006.

Dürst Stucki, M., Schlunegger, F., Christener, F., Otto, J. C., and Götz, J.: Deepening of inner gorges through subglacial meltwater - An example from the UNESCO Entlebuch area, Switzerland, Geomorphology, 139-140, 506-517, https://doi.org/10.1016/j.geomorph.2011.11.016, 2012.

Duvert, C., Gratiot, N., Evrard, O., Navratil, O., Némery, J., Prat, C., and Esteves, M.: Drivers of erosion and suspended sediment transport in three headwater catchments of the Mexican Central Highlands, Geomorphology, 123, 243-256, https://doi.org/10.1016/j.geomorph.2010.07.016, 2010.

Fatichi, S., Rimkus, S., Burlando, P., Bordoy, R., and Molnar, P.: High-resolution distributed analysis of climate and anthropogenic changes on the hydrology of an Alpine catchment, J. Hydrol., 525, 362-382, https://doi.org/10.1016/j.jhydrol.2015.03.036, 2015.

Ferguson, R. I.: River Loads Underestimated by Rating Curves, Water Resour. Res., 22, 74-76, https://doi.org/10.1029/WR022i001p00074, 1986.

Francipane, A., Ivanov, V. Y., Noto, L. V., Istanbulluoglu, E., Arnone, E., and Bras, R. L.: TRIBS-Erosion: A parsimonious physically-based model for studying catchment hydro-geomorphic response, Catena, 92, 216-231, https://doi.org/10.1016/j.catena.2011.10.005, 2012.

Frei, C. and Schär, C.: A precipitation climatology of the Alps from high-resolution rain-gauge observations, Int. J. Climatol., 18, 873-900, https://doi.org/10.1002/(SICI)10970088(19980630)18:8<873::AID-JOC255>3.0.CO;2-9, 1998.

Fryirs, K.: (Dis)Connectivity in catchment sediment cascades: A fresh look at the sediment delivery problem, Earth Surf. Proc. Land., 38, 30-46, https://doi.org/10.1002/esp.3242, 2013.

Fryirs, K. and Brierley, G. J.: Slope - channel decoupling in Wolumla catchment, New South Wales, Australia : the changing nature of sediment sources following European settlement, Catena, 35, 41-63, https://doi.org/10.1016/S03418162(98)00119-2, 1999.

Fryirs, K., Brierley, G. J., Preston, N. J., and Spencer, J.: Catchmentscale (dis)connectivity in sediment flux in the upper Hunter catchment, New South Wales, Australia, Geomorphology, 84, 297-316, https://doi.org/10.1016/j.geomorph.2006.01.044, 2007.

Fuller, C. W., Willett, S. D., Hovius, N., and Slingerland, R.: Erosion Rates for Taiwan Mountain Basins: New Determinations from Suspended Sediment Records and a Stochastic Model of Their Temporal Variation, J. Geol., 111, 71-87, https://doi.org/10.1086/344665, 2003.

Gao, P.: Understanding watershed suspended sediment transport, Prog. Phys. Geogr., 32, 243-263, https://doi.org/10.1177/0309133308094849, 2008.

Hancock, G., Evans, K., Willgoose, G., Moliere, D., Saynor, M., and Loch, R.: Medium-term erosion simulation of an abandoned mine site using the SIBERIA landscape evolution model, Aust. J. Soil Res., 38, 249-263, 2000.

Hancock, G. R., Webb, A. A., and Turner, L.: Sediment transport in forested head water catchments - Calibration and validation of a soil erosion and landscape evolution model, J. Hydrol., 554, 12-23, https://doi.org/10.1016/j.jhydrol.2017.08.049, 2017.

Heckmann, T., Cavalli, M., Cerdan, O., Foerster, S., Javaux, M., Lode, E., Smetanová, A., Vericat, D., and Brardinoni, F.: Indices of sediment connectivity: opportunities, challenges and limitations, Earth-Sci. Rev., 187, 1-32, https://doi.org/10.1016/j.earscirev.2018.08.004, 2018.

Hinderer, M., Kastowski, M., Kamelger, A., Bartolini, C., and Schlunegger, F.: River loads and modern denudation of the Alps - A review, Earth-Sci. Rev., 118, 11-44, https://doi.org/10.1016/j.earscirev.2013.01.001, 2013.

Horowitz, A. J.: An evaluation of sediment rating curves for estimating suspended sediment concentrations for subsequent flux calculations, Hydrol. Process., 17, 3387-3409, https://doi.org/10.1002/hyp.1299, 2003.

Kasten, F. and Czeplak, G.: Solar and terrestrial radiation dependent on the amount and type of cloud, Sol. Energy, 24, 177-189, https://doi.org/10.1016/0038-092X(80)90391-6, 1980.

Kondolf, G. M.: Hungry water: Effects of dams and gravel mining on river channels, Environ. Manage., 21, 533-551, https://doi.org/10.1007/s002679900048, 1997.

Lang, A., Bork, H.-R., and Preston, N.: Changes in sediment flux and storage within a fluvial system : some examples from the Rhine catchment, Hydrol. Process., 3334, 3321-3334, https://doi.org/10.1002/hyp.1389, 2003.

Liu, Z. and Todini, E.: Towards a comprehensive physically-based rainfall-runoff model, Hydrol. Earth Syst. Sci., 6, 859-881, https://doi.org/10.5194/hess-6-859-2002, 2002.

Mahoney, D. T., Fox, J. F., and Al Aamery, N.: Watershed erosion modeling using the probability of sediment connectivity in a gently rolling system, J. Hydrol., 561, 862-883, https://doi.org/10.1016/j.jhydrol.2018.04.034, 2018.

Malmon, D. V., Dunne, T., and Reneau, S. L.: Stochastic Theory of Particle Trajectories through Alluvial Valley Floors, J. Geol., 111, 525-542, https://doi.org/10.1086/376764, 2003.

Mekonnen, M., Keesstra, S. D., Stroosnijder, L., Baartman, J. E., and Maroulis, J.: Soil Conservation Through Sediment Trapping: A Review, Land Degrad. Dev., 26, 544-556, https://doi.org/10.1002/ldr.2308, 2015.

MeteoSwiss: IDAWEB, available at: https://gate.meteoswiss.ch/ idaweb/login.do, last access: 15 August 2019.

Misset, C., Recking, A., Legout, C., Poirel, A., Cazilhac, M., Esteves, M., and Bertrand, M.: An attempt to link suspended load hysteresis patterns and sediment sources configuration in alpine catchments, J. Hydrol., 576, 72-84, https://doi.org/10.1016/j.jhydrol.2019.06.039, 2019.

Montgomery, D. R.: Soil erosion and agricultural sustainability, P. Natl. Acad. Sci. USA, 104, 13268-13272, https://doi.org/10.1073/pnas.0611508104, 2007.

Nearing, M. A., Foster, G. R., Lane, L. J., and Finkner, S. C.: A Process-Based Soil Erosion Model for USDA-Water Erosion Prediction Project Technology, T. ASAE, 32, 1587-1593, 1989.

Nearing, M. A., Pruski, F. F., and O’Neal, M. R.: Expected climate change impacts on soil erosion rates: A review, J. Soil Water Conserv., 59, 43-50, 2004.

Norton, K. P., von Blanckenburg, F., Schlunegger, F., Schwab, M., and Kubik, P. W.: Cosmogenic nuclide-based investigation of spatial erosion and hillslope channel coupling in the tran- 
sient foreland of the Swiss Alps, Geomorphology, 95, 474-486, https://doi.org/10.1016/j.geomorph.2007.07.013, 2008.

Olarieta, J. R., Besga, G., Rodríguez, R., Usón, A., Pinto, M., and Virgel, S.: Sediment enrichment ratios after mechanical site preparation for Pinus radiata plantation in the Basque Country, Geoderma, 93, 255-267, 1999.

Pappas, C., Fatichi, S., Rimkus, S., Burlando, P., and Huber, M. O.: The role of local-scale heterogeneities in terrestrial ecosystem modeling, J. Geophys. Res.-Biogeo., 120, 341-360, https://doi.org/10.1002/2014JG002735, 2015.

Parkyn, S. M., Davies-Colley, R. J., Cooper, A. B., and Stroud, M. J.: Predictions of stream nutrient and sediment yield changes following restoration of forested riparian buffers, Ecol. Eng., 24, 551-558, https://doi.org/10.1016/j.ecoleng.2005.01.004, 2005.

Paschalis, A., Fatichi, S., Molnar, P., Rimkus, S., and Burlando, P.: On the effects of small scale space-time variability of rainfall on basin flood response, J. Hydrol., 514, 313-327, https://doi.org/10.1016/j.jhydrol.2014.04.014, 2014.

Peleg, N., Skinner, C., Fatichi, S., and Molnar, P.: Temperature effects on the spatial structure of heavy rainfall modify catchment hydro-morphological response, Earth Surf. Dynam., 8, 17-36, https://doi.org/10.5194/esurf-8-17-2020, 2020.

Pelletier, J. D.: A spatially distributed model for the longterm suspended sediment discharge and delivery ratio of drainage basins, J. Geophys. Res.-Earth, 117, 1-15, https://doi.org/10.1029/2011JF002129, 2012.

Peucker-Ehrenbrink, B.: Land2Sea database of river drainage basin sizes, annual water discharges, and suspended sediment fluxes, Geochem. Geophy. Geosy., 10, 1-10, https://doi.org/10.1029/2008GC002356, 2009.

Pimentel, D., Allen, J., Beers, A., Guinand, L., Linder, R., McLaughlin, P., Meer, B., Musonda, D., Perdue, D., Poisson, S., Siebert, S., Stoner, K., Salazar, R., and Hawkins, A.: World Agriculture and Soil Erosion, BioScience, 37, 277-283, https://doi.org/10.2307/1310591, 1987.

Prosser, I. P. and Rustomji, P.: Sediment transport capacity relations for overland flow, Prog. Phys. Geogr., 24, 179-193, https://doi.org/10.1177/030913330002400202, 2000.

Rickenmann, D., Badoux, A., and Hunzinger, L.: Significance of sediment transport processes during piedmont floods: The 2005 flood events in Switzerland, Earth Surf. Proc. Land., 41, 224230, https://doi.org/10.1002/esp.3835, 2016.

Schlunegger, F. and Schneider, H.: Relief-rejuvenation and topographic length scales in a fluvial drainage basin, Napf area, Central Switzerland, Geomorphology, 69, 102-117, https://doi.org/10.1016/j.geomorph.2004.12.008, 2005.

Schmidt, J. C. and Wilcock, P. R.: Metrics for assessing the downstream effects of dams, Water Resour. Res., 44, W04404, https://doi.org/10.1029/2006WR005092, 2008.

Schmidt, S., Ballabio, C., Alewell, C., Panagos, P., and Meusburger, K.: Filling the European blank spot-Swiss soil erodibility assessment with topsoil samples, J. Plant Nutr. Soil Sc., 181, 737748, https://doi.org/10.1002/jpln.201800128, 2018.

Schoonover, J. E., Williard, K. W. J., Zaczek, J. J., Mangun, J. C., and Carver, A. D.: Agricultural sediment reduction by giant cane and forest riparian buffers, Water Air Soil Poll., 169, 303-315, https://doi.org/10.1007/s11270-006-3111-2, 2006.

Schwab, M., Rieke-Zapp, D., Schneider, H., Liniger, M., and Schlunegger, F.: Landsliding and sediment flux in the Cen- tral Swiss Alps: A photogrammetric study of the Schimbrig landslide, Entlebuch, Geomorphology, 97, 392-406, https://doi.org/10.1016/j.geomorph.2007.08.019, 2008.

Schwarb, M.: The alpine precipitation climate evaluation of a highresolution analysis scheme using comprehensive rain-gauge data, ETH Zurich Research Collection, https://doi.org/10.3929/ethz-a010782581, 2000.

Seeger, M., Errea, M. P., Beguería, S., Arnáez, J., Martí, C., and García-Ruiz, J. M.: Catchment soil moisture and rainfall characteristics as determinant factors for discharge/suspended sediment hysteretic loops in a small headwater catchment in the Spanish pyrenees, J. Hydrol., 288, 299-311, https://doi.org/10.1016/j.jhydrol.2003.10.012, 2004.

Shah, S. M., O'Connell, P. E., and Hosking, J. R.: Modelling the effects of spatial variability in rainfall on catchment response. 2. Experiments with distributed and lumped models, J. Hydrol., 175, 89-111, https://doi.org/10.1016/S0022-1694(96)80007-2, 1996.

Siakeu, J., Oguchi, T., Aoki, T., Esaki, Y., and Jarvie, H. P.: Change in riverine suspended sediment concentration in central Japan in response to late 20th century human activities, Catena, 55, 231254, https://doi.org/10.1016/S0341-8162(03)00120-6, 2004.

Smith, B. P., Naden, P. S., Leeks, G. J., and Wass, P. D.: The influence of storm events on fine sediment transport, erosion and deposition within a reach of the River Swale, Yorkshire, UK, Sci. Total Environ., 314-316, 451-474, https://doi.org/10.1016/S0048-9697(03)00068-8, 2003.

SwissAlti3D: SwissAlti3D - The high precision digital elevation model of Switzerland, available at: https://shop.swisstopo.admin ch/en/products/height_models/alti3D, last access: 6 April 2017.

Syvitski, J. and Kettner, A.: Sediment flux and the anthropocene, Philos. T. Roy. Soc. A, 369, 957-975, https://doi.org/10.1098/rsta.2010.0329, 2011.

Syvitski, J., Vörösmarty, C. J., Kettner, A. J., and Green, P.: Impact of Humans on the Flux of Terrestrial Sediment to the Global Coastal Ocean, Science, 308, 376-380, https://doi.org/10.1126/science.1109454, 2005.

Tsuruta, K., Hassan, M. A., Donner, S. D., and Alila, Y.: Development and Application of a Large-Scale, Physically Based, Distributed Suspended Sediment Transport Model on the Fraser River Basin, British Columbia, Canada, J. Geophys. Res.-Earth, 123, 2481-2508, https://doi.org/10.1029/2017JF004578, 2018.

Van Den Berg, F., Schlunegger, F., Akçar, N., and Kubik, P.: ${ }^{10} \mathrm{Be}$-derived assessment of accelerated erosion in a glacially conditioned inner gorge, Entlebuch, Central Alps of Switzerland, Earth Surf. Proc. Land., 37, 1176-1188, https://doi.org/10.1002/esp.3237, 2012.

Van Rompaey, A. J., Verstraeten, G., Van Oost, K., Govers, G., and Poesen, J.: Modelling mean annual sediment yield using a distributed approach, Earth Surf. Proc. Land., 26, 1221-1236, https://doi.org/10.1002/esp.275, 2001.

Vercruysse, K., Grabowski, R. C., and Rickson, R. J.: Suspended sediment transport dynamics in rivers: Multi-scale drivers of temporal variation, Earth-Sci. Rev., 166, 38-52, https://doi.org/10.1016/j.earscirev.2016.12.016, 2017.

Wainwright, J., Turnbull, L., Ibrahim, T. G., Lexartza-Artza, I., Thornton, S. F., and Brazier, R. E.: Linking environmental régimes, space and time: Interpretations of structural 
and functional connectivity, Geomorphology, 126, 387-404, https://doi.org/10.1016/j.geomorph.2010.07.027, 2011.

Walling, D. E.: Assessing the accuracy of suspended sediment rating curves for a small basin, Water Resour. Res., 13, 531-538, https://doi.org/10.1029/WR013i003p00531, 1977.

Walling, D. E.: The sediment delivery problem, J. Hydrol., 65, 209_ 237, https://doi.org/10.1016/0022-1694(83)90217-2, 1983.

Walling, D. E.: Human impact on land-ocean sediment transfer by the world's rivers, Geomorphology, 79, 192-216, https://doi.org/10.1016/j.geomorph.2006.06.019, 2006.

Walling, D. E. and Webb, B. W.: The reliability of suspended sediment load data, J. Am. Med. Assoc., 248, 2180, https://doi.org/10.1001/jama.248.17.2180, 1982.

Wass, P. D. and Leeks, G. J. L.: Suspended sediment Fluxes in the Humber catchment , UK, Hydrol. Process., 13, 935-953, https://doi.org/10.1002/(SICI)10991085(199905)13:7<935::AID-HYP783>3.0.CO;2-L, 1999.

Wittmann, H., von Blanckenburg, F., Kruesmann, T., Norton, K. P., and Kubik, P. W.: Relation between rock uplift and denudation from cosmogenic nuclides in river sediment in the Central Alps of Switzerland, J. Geophys. Res.-Earth, 112, 1-20, https://doi.org/10.1029/2006JF000729, 2007.
Woolhiser, D. A., Smith, R. E., and Goodrich, D. C.: KINEROS, A Kinematic Runoff and Erosion Model: Documentation and User Manual. U.S. Department of Agriculture, Agricultural Research Service, ARS-77, 130 pp., 1990.

Yang, D., Kanae, S., Oki, T., Koike, T., and Musiake, K.: Global potential soil erosion with reference to land use and climate changes, Hydrol. Process., 17, 2913-2928, https://doi.org/10.1002/hyp.1441, 2003.

Yu, L.: The Huanghe (Yellow) River: A review of its development, characteristics, and future management issues, Cont. Shelf Res., 22, 389-403, https://doi.org/10.1016/S0278-4343(01)00088-7, 2002.

Zabaleta, A., Martínez, M., Uriarte, J. A., and Antigüedad, I.: Factors controlling suspended sediment yield during runoff events in small headwater catchments of the Basque Country, Catena, 71, 179-190, https://doi.org/10.1016/j.catena.2006.06.007, 2007. 